IJ§ER

ISSN: 2149-5939
International Journal of Social Sciences and Education Research

Online, https://dergipark.org.tr/tr/pub/ijsser

Volume: 6(2), 2020

Research Article

\title{
At the edge of a global problem entitled corona: The rooted education policy of China
}

\author{
İlknur Kazaz ${ }^{1}$
}

Received date: 16 / 05 / 2020

Accepted date: 28 / $06 / 2020$

\begin{abstract}
While the world is struggling with the corona virus spreading from China, it brings to mind the question of whether it will bring other problems. Of course, it is unthinkable for a crowded and rooted country like China to stop education. Chinese people continue to hold on to life with all their strengths. So what is the reason for this commitment of the Chinese to education? What lies beneath? Where does Turkey stand in this situation?
\end{abstract}

Keywords: Foreign language education; language policy, PISA, Chinese education system

\section{Introduction}

During the last decade, new efforts have aimed at improving foreign language education worldwide. There is an increased awareness among researchers and educators about the language learning patterns and related problems that students go through within different educational systems and learning philosophies. The spread of English has accelerated worldwide from World War II onwards. Globalization, scientific inventions, technological innovations, economy and diplomacy have contributed to this situation in the forthcoming years. English has been nominated as the most prestigious foreign language in nearly all countries. Knowledge of English is an indispensable part of the modern world. This paper gives an overview of the history, ideology, structure, centralization, development and political maxims of English teaching and learning in the educational framework and discusses the characteristics of learners, the English language teaching environment and the contemporary classroom practices in China in comparison to Turkey under Covid-19 perspective. The reason for the selection of this country for this paper is that it has a unique teaching system henceforth a different approach towards foreign language learning.

\subsection{Research questions}

a) Why isn't the Chinese education system affected adversely by the Covid-19 pandemic?

b) What are the reasons for their success at education even in case of a global crisis?

\subsection{The Purpose of the study}

As the result of socio-economic problems, political tensions and misapplications due to the Covid-19 outbreak, many problems are expected in education which might decrease the effectiveness and quality of education. The challenges faced by the students and teachers could have influenced the national education in China, but it didn't. The Chinese Government succeeded both in

${ }^{1}$ Lecturer, Karadeniz Technical University, Trabzon, Turkey, ilknurkazaz@ktu.edu.tr 
Kazaz, İ. (2020). At the edge of a global problem entitled corona: The rooted education policy of China. International Journal of Social Sciences and Education Research, 6(2), 157-164.

overcoming the health problems ot its citizens and their education policy was not affected in a bad way. How did the Chinese manage to overcome the obstacles in education? The aim of this study is to find the reasons underlying the success at education, the aspects of Chinese policy at corona virus outbreak, and to shed light onto what lies beneath the Chinese power, the ways the Chinese dealt with the problem.
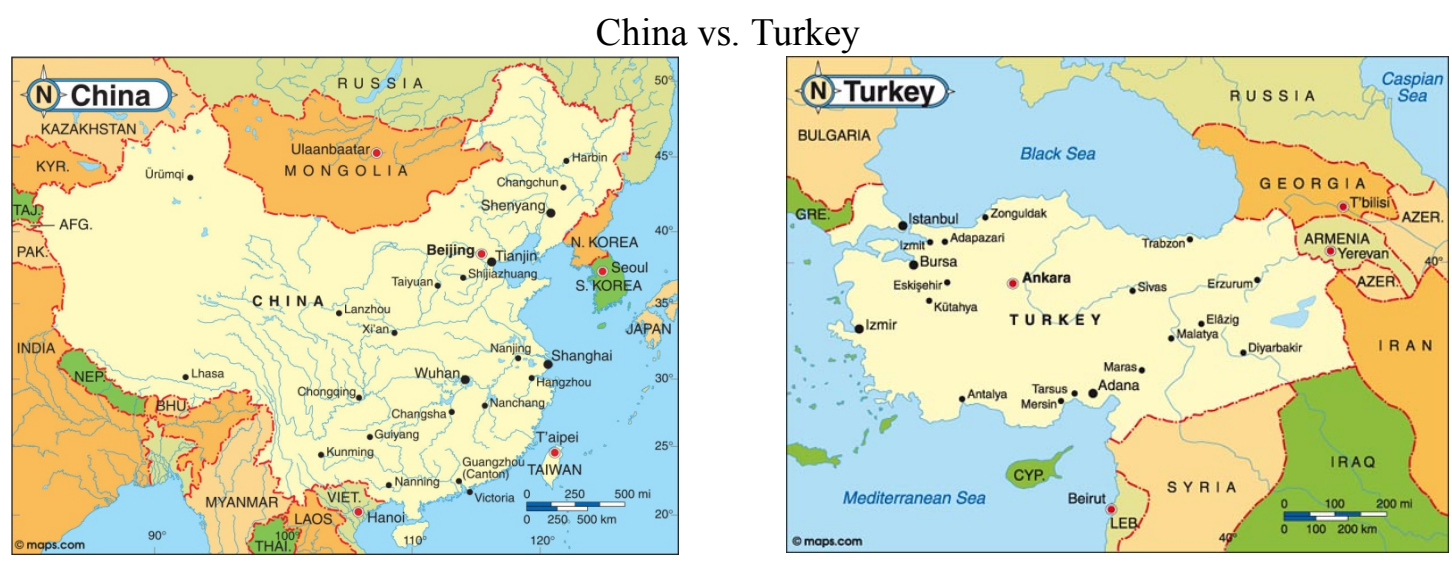

\section{Literature review}

\subsection{The foreign language learning environment in China}

With over 1.36 billion people, the People's Republic of China is the world's most populous country and has the world's largest education system. China has a nine-year compulsory education system, including primary and lower secondary school. Students must take examinations for entry into upper secondary schools and universities. In Chinese education system, foreign language acquisition is conditioned mainly into the classroom. The foreign language acquisition environment is poor and no authentic materials and tasks are observed (Wong, 2007). In fact, there is little out-of-class activity. Foreign language proficiency is mainly through formal teaching and teachers, furthermore the textbooks are the principal sources of foreign language knowledge. The English teachers are Chinese originated, they were trained in Chinese institutions by Chinese teachers. English medium newspapers, magazines, radio programmes, TV programmes are few in number. Learning English has extrinsic motives. It is thought to give the individuals opportunities for higher education, career advancement, better salaries or for study and travel abroad (Gao, 2008). The advancements in international business and trade requires graduates to be proficient in the productive language skills; respectively writing and speaking. Learning English is viewed as a door-opener for self-development and material gain. For the country, education has a strategic value as well. It is is a medium for national, political and economic goals. Macro policy decisions have been made by the central government to accelerate the modernisation process. Since 1985, a series of ELT reforms has been made at different educational levels to meet the needs of the 21st century. In the newly formed syllabuses the use of English is regarded as a tool for communication and a means to acquire knowledge from the European countries. In recent years, the Chinese government has been promoting reforms in teaching methodologies, school governance and management systems. Since 2001, the basic education curriculum reform has emphasised, the learning process and students' attitudes towards learning in addition to the content to be taught, encouraging active and creative problem solving, interactive and co-operative learning, and less reliance on passive rote learning. After participation in PISA 2015, the learning 
Kazaz, İ. (2020). At the edge of a global problem entitled corona: The rooted education policy of China. International Journal of Social Sciences and Education Research, 6(2), 157-164.

time in school and academic requirements are specified, and students are required to meet all the requirements before they can get a diploma. Schools are exerting great efforts to provide students with a variety of elective courses and not all students are required to take the same courses. Research-based learning is encouraged in order to promote creativity, critical thinking and social practice. Students can identify their own research topics with the help of teachers. Students are now encouraged to take a more active role in classroom teaching. The examination system is also undergoing gradual reform. No entrance examinations are required in compulsory education. Students attend schools in their neighborhood. Admission to upper secondary school is not based on a single entrance exam. More emphasis has been placed on comprehensive evaluations, including students' ideological and moral qualities, physical and mental health, artistic accomplishments and involvement in the community.

\subsection{Historical background}

Chinese learners are always described as rote-learners who are passive, spoon-fed, quiet, unquestioning, motivated, obedient, disciplined and so on (Biggs, 1999). Chinese teachers are authoritative and dominant (Cortazzi \& Jin, 1996b) while the education system is often examinationoriented (Wong 2007). The prevalent opinion is that the teacher is in control of knowledge and delivery, while learners solely listen and remember. The examinations are of crucial importance, they pose an ultimate goal for teachers and learners. The learning habits and teaching patterns have particularly deep roots. Modern education in China is heavily influenced by history, traditions and culture (Simpson, 2008). In line with this, Confucian orthodoxy is visible in Chinese learning. The Confucian influences are present in the education system and they are reflected in its teaching practices and learners' behaviour (Reynolds \& Farrell, 1996), classroom discourse (Scollon, 1999), the curriculum (PRC State Education Committee, 1996), teacher-learner relationships (Chen \& Drover, 1997) and textbook writing (Adamson \& Morris, 1997).

Confucius paradigm views education as a tool for achieving personal perfection. According to Confucius, moral values are transmitted by the teacher. The teacher is the one who conveys the moral principles recorded in texts or learned from ancestors. The teacher's main duty is to transmit the ideological qualifications to the disciples which would lead to moral superiority. The teacher is in control of knowledge and delivery. For the creation of a successful learning environment, learners should be obedient, co-operative and polite. They should stick to the role and relationship principles which are core themes of the Confucian concept. Revolts in this superior-subordinate relationship would be envisaged improper and disrespectful of pecking order and hierarchy. The best way to remember these Confucian dogmas are word-by-word memorization. As supported by Scollon(1999), these philosophical patterns are vital to Chinese learners of English. The present ideology of teaching and learning foreign languages is interrelated with these historical and cultural roots.

Turkey has roots with its history in foreign language education as well. The introduction of English language into the Turkish education system dates back to The Tanzimat Period (18391876), the second half of the nineteenth century, which marks the beginning of the Westernization movements in the education system (Kirkgoz, 2005). This period plays an important role in education because it is the starting point of the Westernization movements. The first attempts to teach a western language rose out of the need to transfer military technology from the west in the eighteenth century. During the Ottoman period Grammar Translation Method was used to translate French into the written Ottoman Turkish. The interest in the learning and teaching of English 
Kazaz, İ. (2020). At the edge of a global problem entitled corona: The rooted education policy of China. International Journal of Social Sciences and Education Research, 6(2), 157-164.

developed after World War II. Until 1941 the method for teaching languages was the grammar translation method which is based on reading comprehension and translation mainly due to the dominance of Arabic on the Ottoman Turkish. After the war there have been social, cultural, economic, technological, and political developments in the world. The alphabet was changed fom Arabic to Latin. So, the methods used in language education were also changed. Direct Method became popular because every day language became the content of the courses. After a while, American schools started using Audiolingualism. Dialogues filled with imitation and repetition for provision of new vocabulary and structures to the students were made use of. Like China, Turkey started foreign language education with the grammar translation method and trialled many different methods so forth.

\section{Method}

Qualitiative method was chosen for this study. Interpretivist grounded research design was employed. A systematic comparative analysis was preferred via subjective interpretation of the data by identifying themes or patterns. The comparative method "combines systematic data collection, coding, and analysis with theoretical sampling in order to generate theory that is integrated, close to the data, and expressed in a form clear enough for further testing" (Conrad, Neumann, Haworth, \& Scott, 1993, p. ). For grounded theory, as suggested in the literature (Strauss \& Corbin; Taylor \& Bogdan, 1998; Creswell, 2007; Locke, 1996), making constant comparisons and applying theoretical sampling are necessary strategies.

\section{Findings and discussion}

\subsection{Curriculum}

The aforementioned concept of uniformity of Chinese is reflected in the national syllabus, the choice of textbooks, the reliance on teachers' boks and lesson planning as well. The College English Syllabus for Students of Arts and Science is used nationwide by 4 million non-English major university students. It includes 280 hours of teaching for the non-English major freshman and sophomore students. It covers the content of the teaching of pronunciation, vocabulary, grammar, reading, listening, writing and speaking skills. The micro-skills, inventories of vocabulary, grammatical summaries, functions and notions are included as well. Guidelines for teaching, appropriate approaches and advice on the use of teaching aids exist for the teachers' reference. When there is a curricular reform in China, a new set of recommended textbooks appears. Now that, the national examination is designed to test the students' textbook knowledge, there is no other way than teaching with the textbook. However, Richards (1993) warns that over-dependence on textbooks would result in the negligence of students' needs and deskilling of teachers: there would be a reduction in the teacher's role and a reduction in the quality of teachers' decision making and pedagogical reasoning (p.45). Even the revised version of College English syllabus states that the teaching materials are intended to provide the best language examples for classroom teaching. Hereby, the textbook is presented as the centre of classroom teaching. Oncemore, the traditional teacher-centred and textbook-centred methods are consolidated. In China, syllabuses set the standards to reach national goals or curriculum reforms, (Educational Statistics Yearbook of China, 2004) to prepare the students for the national examinations. Teachers treat the syllabus as a vesicle. They never deviate from the published syllabus and the recommended textbooks. Textbooks have a dictation on the teaching methodology of the teacher and the format of the courses. Such kind of control allocates very scarce flexibility in the content, scheduling, teaching 
Kazaz, İ. (2020). At the edge of a global problem entitled corona: The rooted education policy of China. International Journal of Social Sciences and Education Research, 6(2), 157-164.

approaches and the materials used. In Turkey, the Ministry of National Education plans the curricular changes and provides administrative arrangements and supervision related to education. In the 1980s when the ELT syllabus was attempted to be revised, communicative language teaching was integrated into the curriculum. The second change in the ELT policy was in 1997. The students started learning English at the fourth grade. This exposure to the language would help acquire the language more successfully. New curriculum is a much more comprehensive and elaborate in many aspects compared with the previous one. Use of games, stories, songs, dramatization and model materials are emphasized.

\subsection{Teaching approach}

The established belief of teacher's being the supplier of knowledge naturally shows itself in the Audio-lingual and the Grammar-Translation approaches when teaching and learning the foreign language in China (Ma,1999). Teachers stand in front of the classroom and students sit in their desks looking at the blackboard. The teaching is in lecture mode. Students memorise the teacher's discourse and try to reproduce it in examination. Success is equated with sticking to traditional virtues, such as personal modesty, self-discipline, and obedience to authority. Standardisation of teaching is also maintained through lesson preparation. Each week, all teachers teaching at the same grade discuss the schedule and plan the lesson in the primary or secondary schools. Teachers also attend public showcase lessons arranged by the Provincial Education Committee, in order to acquire the teaching skills of the model teacher. Similarly, in higher education, collective lesson planning is organized by the teaching and research group. Instructors teaching at the same level prepare Chinese translation of the vocabulary, write down a detailed lesson plan, prepare quizzes and exchange their ideas in weekly meetings. The educational authorities urge the teachers to stick closely to the national syllabus and the recommended textbooks and to sustain the teacher-centred approach. This teacher-centred and textbook-centred approach creates equal learning conditions for every student as reported by Ross (1992).

In response to the changing economic and political situations of Turkey, the teaching theory is mainly concerned with educating the citizens who will be able to adopt and learn new language skills at different levels in their educational lives. Foreign language teachers are professionally competent and well-trained in order to close the gap between policy rhetoric and classroom reality. "Foreign Language Teaching Improvement Project', was organized in March 2011 in Turkey. In this project opening of English cafes at schools, demonstration of popular cartoons during courses and hiring of native speakers to work in collaboration with Turkish English Language Teachers were planned.

\subsection{Learning behaviour}

Imitation and repetition are widespread in Chinese classrooms. The teacher pronunciates and intonates loudly. Then learners are asked to produce the exact reproduction. Imitation is believed to signify successful learning. Therefore, oral drills constitute an important classroom activity for learners. Grammar points and new words are explained as well in class, and then the students are required home assignments e.g. completing the workbook and the mechanical exercises prepared by the teacher. They are regarded as the only way to learn the foreign language. Although many foreign language theoricians oppose to rote learning, the method is highly esteemed for Chinese learners, teachers and textbook writers. Memorization is mentioned explicitly in the syllabus as one of the abilities to be developed alongside language skills (English Syllabus for Senior Secondary, 1995). In fact, memorization is a learning strategy transferred from first language 
Kazaz, İ. (2020). At the edge of a global problem entitled corona: The rooted education policy of China. International Journal of Social Sciences and Education Research, 6(2), 157-164.

acquisition to foreign language acquisition. When they begin to acquire the foreign language in the secondary school, they try to apply the same strategy used when they were 3 or 4 years old. Memorisation via repetitive learning transmits the learners to understanding (Haller et al., 2007).

The ongoing reforms have led to great improvements in Turkey. Students graduate from private schools and universities with English medium instruction. However, at present, official textbooks and curricula fail to take account of the varying levels and needs of students. This lack of interest has led to a disengagement of students from lesson content in English. Students turn up to the class, complete textbook exercises and learn nothing. Current textbooks do not differentiate according to student needs. Almost all classrooms have a layout where students sit together, in pairs on bench seats. However, teachers fail to use this seating arrangement to organise students into pairs and groups for communicative language practice.

\subsection{Examinations}

Through success in high-stake public examinations learners can gain social status in China. The nation-wide examinations determine whether the students furher study at a key university or at an ordinary one. In the days of the Higher Institutions Entrance Examination the vehicles are banned from blowing horns. Police ensures the traffic flow to all examination centres. Testing in secondary schools is again extremely frequent. It measures the progress of the students and determines the students who are left behind. The national examinations in China are all syllabusreferenced. The teaching syllabus is the examination syllabus at the same time. Thus, more teaching and more recitation will lead to higher marks. The performance of the students in the examination will reciprocally portray teachers' ability and status. The teacher's mission, imposed by the education system, society, administrators and parents, is to get the students to achieve high scores in the exam.

Likewise, in Turkey, the present teacher-centric, classroom practice focuses on students learning how to answer teachers' questions, how to complete written exercises in a textbook, and how to pass a grammar-based test. Thus grammar-based grammar tests drive the teaching and learning process from Grade 4 onwards. This type of classroom practice dominates all English lessons and is a causal factor for the failure of Turkish students to speak and understand English.

\subsection{The contemporary English classroom}

Confucian ideology still reigns the philosophy of education in modern China. Nevertheless, the novel English syllabuses at primary, secondary and higher education levels have put an emphasis on the use of English. The national examinations were required to include a test of spoken English. Although the revised syllabuses retained the traditional ways of teaching and learning, the teachers were asked to make tremendous changes in their approach to language. They moved from knowledge to competence in approaches, from explanation to elicitation in teaching, from recitation to utilization in learning and from authority to interaction in methods. Teachers suffered from a sense of ideology conflict, a clash in cultural beliefs, however, and did not receive adequate retraining (Tang, 2001). Due to the pressure for change, eclecticism is widely promoted and accepted by teachers as the most appropriate approach (Hu, 2005b). Although communicative language teaching was preferred for some time because of its flexible nature, most teachers now have turned back to the grammar-translation method again. The classrooms in China fail to involve interaction and modern teaching methods even though being equipped with multi-media facilities 
Kazaz, İ. (2020). At the edge of a global problem entitled corona: The rooted education policy of China. International Journal of Social Sciences and Education Research, 6(2), 157-164.

(Jiang, 2008). There is no such thing as good or bad language teaching, there is only teaching that is appropriate or inappropriate (Spolsky, 1989) or effective or ineffective (Harmer, 2001).

To sum up, education philosophy in China can be defined to be authoritarian, exam oriented, strict disciplined and to have expository teaching methods with an unquestioning acceptance of the teacher as the sole giver of knowledge. The Confucian culture with its extremely strong heritage prevails in the Chinese education system through a highly centralized curricula, and textbook-centredness, teacher-centredness and examination-centredness (OuYang, 2000). This preserved model of teaching and learning suits the best to the Chinese. The ideology and pride of the Chinese towards their own cultures, society and history prevent them from accepting new approaches and methods since they think it is a threat to their traditions and culture. Chinese framework of education which includes such a unique trait deserves recognition and respect from the western pedagogy. For this reason, problems like corona virus do not prevent the uncompetitive Chinese from learning and education. When education is considered, they are unstoppable in other words.

\section{Conclusion}

China's education system has always been an important component of life. With the advancements in technology it has reached the maximum accomplishment levels as well. Although there has been complaints during this period about the poor quality of some online classes, the low ratings of learning apps, the cancellation of high-stake exams, the Chinese are still highly successful at education, the origins of which extend to the Confucian paradigm. Chinese government has imposed strict measures to stop the spread of the Covid-19 pandemic and to ensure the continual of education. The Chinese keep teaching and learning as follows:

a) In China, schools and universities are employing a mix of innovative and novel approaches for the survival of the right to education.

b) Face-to-face teaching activities are not allowed.

c) Chinese universities and colleges have been postponed.

d) Ministry of Education has launched 'Disrupted classes, undisrupted learning' project for over 270 million students with flexible online learning.

e) The universities administer multi-dimensional learning evaluation, and the students are credited out of online achievements.

f) Faculty are permitted to choose among appropriate learning platforms they are familiar with such as Blackboard, TronClass, Zoom, Classin, Wechat group, and QQ group.

In short, Coronavirus outbreak has accelerated development of digital education in Chinese education. Henceforth; internet, big data, Artificial Intelligence, 5G, and cloud-based platforms are utilized. In the world of digital natives, the education somehow proceeds with the integration of online teaching into curricular systems which also bring out potential development opportunities (Jandrić, 2020) together for the future.

\section{References}

Adamson, B., \& Morris, P. (1997). The English curriculum in the People's Republic of China. Comparative Education Review, 41(1), 3-26. 
Kazaz, İ. (2020). At the edge of a global problem entitled corona: The rooted education policy of China. International Journal of Social Sciences and Education Research, 6(2), 157-164.

Biggs, J. (1999, April). Understanding chinese learners. Paper presented at the Seminar on Focus on the Learner Series, City University of Hong Kong, Hong Kong, China.

Chen, D., \& Drover, G. (1997). Teaching and learning for overseas students: the Hong Kong connection. In D. McNamara, \& R. Harris (Eds.), Overseas students in Higher Education - Issues in teaching and learning. London; New York: Routledge.

Conrad, C., Neumann, A., Haworth, J. G., \& Scott, P. (1993). Qualitative research in higher education: Experiencing alternative perspective and approaches. Needham Heights, MA: Ginn Press.

Creswell, J. W. (2007). Research design: Qualitative and quantitative approaches. (2nd ed.). Thousand Oaks, CA: Sage.

Cortazzi, M., \& Jin, L. (1996b). English teaching and learning in China. Language Teaching, 29, 61-80.

Gao, X. (2008). You Had to Work Hard 'Cause You Didn't Know Whether You Were Going to Wear Shoes or Straw Sandals!. Journal of Language, Identity, and Education, 7, 169-187.

Haller, C., Fisher, R., and Gapp, R. (2007). Reflection as a means of understanding: ways in which Confucian heritage students learn and understand organisational behaviour. Multicultural Education \& Technology Journal, 1(1), 6-24.

Harmer, J. (2001). The practice of English language teaching. London: Longman.

Hu, G. (2005b). CLT Is best for China"--An untenable absolutist claim. ELTJ, 59(1), 65-68.

Jandrić, P. (2020). Postdigital research in the time of Covid-19. Postdigital Science and Education, 2, 233238.

Jiang, G. (2008). When a "modern" Chinese meets "traditional" American classes. US China Education Review, 5(5), 60-62.

Kirkgoz, Y. (2005). , in G. Braine (Ed.), Teaching English to the world: History, curriculum, and practice (pp. 159-175). Mahwah: Lawrence Erlbaum Associates.

Locke, K. (1996). Rewriting the discovery of grounded theory after 25 years? Journal of Management Inquiry, 5, 239-246.

Ma, R. (1999). Language learning strategies of a sample of tertiary-level students in the P.R.China. RELC Guidelines, 21(1), 1-11.

Ouyang, H. (2000). Remaking of face and community of practices: an ethnographic study of what ELT reform means to local and expatriate teachers in today's China. Unpublished $\mathrm{PhD}$. thesis, City University of Hong Kong, Hong Kong.

Reynolds, D., \& Farrell, S. (1996). Worlds apart? A review of international surveys of educational achievement involving England. London: Office for Standards in Education.

Richards, J. (1993). Beyond the textbook: the role of commercial materials in language teaching. Perspectives, 5, 43-53.

Ross, H. (1992). Foreign language education as a barometer of modernization. In H. Ruth (Ed.), Education and modernization: the Chinese experience. Oxford; New York: Pergamon Press.

Scollon, R., \& Scollon, S. (1994). The post-Confucian confusion. Research Report, No. 37. Hong Kong: Department of English, City Polytechnic of Hong Kong.

Simpson, S. (2008). Western EFL teachers and East-West classroom-culture conflicts. RELC Journal, 39(3), 381-394.

Spolsky, B. (1989). Conditions for second language learning: introduction to a general theory. New York: OUP.

Tang, E. (2001). Discourse in the Chinese EFL classroom. Paper presented at the BALEAP PIM on Chinese learners", Sheffield, UK.

Taylor, S. J., \& Bogdan, R. (1998). Introduction to qualitative research methods: A guidebook and resource. (3rd ed.). New York: Wiley

Wong, R. (2007). Motivation and strategies to learn English: the case of pre-service teachers of Chinese. Asian ESP Journal, 3(2), 68-82. 